\title{
Job Satisfaction as a Mediating of Leadership Style and Organizational Culture on Employee Performance of Togamas Discount Bookstore, Indonesia
}

\author{
Ida Bagus Sidhi Wirtama ${ }^{1}$, Junianto Tjahjo Darsono ${ }^{2} \&$ Tanto Gatot Sumarsono ${ }^{3}$ \\ ${ }^{1}$ Student on Magister Management Program, University of Merdeka Malang, Indonesia \\ ${ }^{2,3}$ Lecturer in Faculty of Economics and Business, University of Merdeka Malang, Indonesia
}

\begin{abstract}
This study aimed to describe the style of leadership, organizational culture, job satisfaction, and employee performance. In addition, this study also aimed to analyze influence leadership style and organizational culture on employee performance through job satisfaction. Respondents were employees Togamas Discount Bookstore in poor regions. The population in this study were 55 employees Corporate Discount Bookstore Togamas in poor, the data collection method used was census by using the entire amount of the population as a sample. Technical analysis was made using descriptive analysis method, the classical assumption test, test hypotheses and methods of multivariate statistical analysis of completed pathways using linear regression techniques with SPSS statistical software. The results showed that job satisfaction status as a mediating variable that can mediate variables of leadership style and organizational culture on employee performance. Participatory leadership style, attention to accuracy, coworkers, and the ability to cooperate become an important indicator, Employee performance can be built if the employee is satisfied with the leadership styles applied in the company and the company has a good organizational culture.
\end{abstract}

Keywords: Leadership Style, Organizational Culture, Job Satisfaction, Employee Performance.

\section{INTRODUCTION}

Togamas Discount Bookstore in management is divided into two parts, namely the Business Unit or shop and parts Supporting or Corporate or head office. In the Business Unit focuses on sales, while at work Supporting activities focused on helping the system and checking the Business Unit. Corporate employees amounts to approximately 64 employees divided into several divisions which include the division of the Special Team, Finance, Accounting, Tax, Audit \& Stock, IT, HRGA, Admin, Logistics, and Online. Business Unit consists of 26 branch stores spread covers an area of Java and Bali, with the number of employees reached more than 700 employees. The organizational structure at the Business Unit consists of the Area Manager, Store Manager, Department Heads, Supervisors and staff. While section consists Supporting Supporting Head Manager, Division Manager,

With the development of the business unit and the number of employees is of course also needed leadership in managing the company because there will be the problem of how employees are directed in order to produce optimum performance so that corporate objectives can be achieved. To that end, companies should endeavor to ensure that the factors that affect the performance of employees can be fulfilled to the maximum. Leadership relating to the deliberate process of a person to emphasize the strong influence of others, to guide, create a structure, facilitate the activities and relationships within a group or organization [1]. The success of the organization in achieving its objectives depends on leadership that is whether the leadership is able to mobilize all human resources, natural resources, facilities, funds, and the time effectively and efficiently as well as integrated in the management process. Because the leadership is at the core of the organization, management, and administration [2]. Mondiani suggested that leadership is an important thing in a company or organization [3]. Because of the absence of good leadership, the company will not run properly and the performance of each karyawanpun not be achieved well too. The importance of human resources, each company must consider the level of leadership skills and excellent communication and correct all its employees so as to create a good family climate, which in turn can improve employee performance. The increase in effective leadership and the right one in terms of the effectiveness of the employee.

In the Supporting consists of berberapa division led by the Manager or Vice Manager. Manager and ViceManager in Supporting must have leadership styles vary. According to Gibson the company's success is largely determined by the 
effectiveness of the success of leaders and employees of all divisions within the company. Gibson's opinion has the consequence of a lawsuit against the company for more attention to critical aspects that are critical success factors of employee performance leader, so that employees can achieve the performance of employees [4]. The style of a manager in leading downwards had a significant impact on the attitude and performance of employees. Characteristics associated with subordinates and communication process that occurs between leaders and subordinates, it is influenced by the effectiveness of the leader. For employees to work in accordance with the program, then a very large role of a leader. Therefore, a leader in raising the performance of employees is the main thing to keep in mind.

By the age of Discount Bookstore Togamas company that has reached more than 29 years, Discount Bookstore Togamas have an organizational culture that influence the attitudes and behavior of employees in the work. Employee behavior can be influenced by organizational culture. Culture is a common perception held by all members of the organization, so that every employee who became a member of the organization will have values, beliefs and behavior in accordance with the organization. Organizational culture is a part of organizational life that influence behavior, attitudes, and effectiveness of all employees [5]. One of the variables associated with increased performance of the company or organization is the "corporate culture". This variable is usually described by employees in a common forms are believed to be members. Every organization has a culture of each. Culture is drilled, owned and so embraced by the member companies as a strategy that will affect the course of the company's business work.

Discount Bookstore Togamas grow and develop organizational culture contained therein, so as to stimulate the morale of existing human resources so that with a good organizational culture is expected to improve the performance of employees in achieving corporate goals. Bookstore Discounts Togamas have organizational culture intellectual spirit by promoting education as the primary basis for work, have a culture of informal situations work environment promoting work environment more comfortable and conducive to not forget the aspect of modesty and aesthetics and familiarity with the aspects of kinship thus creating the climate mutual benefit both sides. With the organizational culture determines the leader determines the attitude and direction in the lead. Because organizational culture is the basic philosophy of the organization which includes beliefs, norms, and values into the handle all human resources within the organization in carrying out its performance [6]. Cultural organizations can also be expressed as a system of meaning / significance jointly held by members that distinguishes organization to another [7].

Discuss job satisfaction will not be released in the presence of factors that can affect a person's job satisfaction. The issue of job satisfaction will be realized and fulfilled if some of the variables that affect it can support. The variables in question are leadership and organizational culture. Job satisfaction is individualized and has a level of satisfaction varies, one definition of job satisfaction cited by As'ad in the book "Psychology of Industries" Joseph Tiffin, job satisfaction is employee attitudes towards work, the situation work, cooperation between management and fellow employees and the factors that influence job satisfaction, among others; financial satisfaction factor, the factor of physical satisfaction, social satisfaction factors, and factors of psychological satisfaction.

Performance of a company can be said to be successful with a lot to look at factors, such as with a nice view of the poor performance of its employees. Performance is often interpreted as a success that can be achieved. According Bernad \& Russell , the performance is the outcome records generated from a particular job function or kegiaan sutu during a specific time period (performance is difined as the record of the outcomes produced a specified job function or activity duruing a specified time period) [8]. Meanwhile, according to Vroom (in As'ad,) defines performance as the rate how well a person can perform their duties [9]. Porter \& Lowler (in As'ad,) suggests a role succesful achievement of performance as the gain from his actions [9]. A company's performance is a synergy performance of all employees and the entire team / business units. With Discount Bookstore Togamas age who has reached 29 years, of course, the maximum employee performance is expected by the company. More and more employees have maximum performance, the company's overall productivity will be increased so that the company will be able to achieve its vision.

\section{LITERATURE REVIEW}

\subsection{Performance}

Employee performance by Mathis and Jackson is what is done or not done by employees [10]. Furthermore Mangkunagara defines the performance is the result of the quality and quantity of work accomplished by an employee in performing their duties in accordance with the responsibilities given to him [11]. Performance indicators according to Mathis and Jackson is as follows: Quantity, Quality, Timeliness, presence, ability to cooperate [10].

\subsection{Job Satisfaction}

Robbins and Judge stated that job satisfaction is an individual general attitude toward his job in the job where a person is required to interact with colleagues and superiors, follow the rules and policies of the organization meet the performance standards [12]. Hasibuan define job satisfaction as an emotional attitude of fun and love pekerjaaannya. This attitude is reflected by morale, discipline and work performance [13]. Enjoy job satisfaction in the job, off the job, and the combination of inside and outside of 
work. According to Gibson et al, there are five important aspects that affect job satisfaction, namely: Employment, Wages, supervisor or supervisory work, promotional opportunities which is the state the opportunity to advance and co-workers [14].

\subsection{Leadership Style}

Robbins argues style of leadership is the ability to influence a group to achieve a vision or goal [15]. According Thoha, "leadership style is the norm of behavior that is used by a person at the time the person is trying to influence the behavior of others as he sees"[16]. Path-Goal Theory (small path-goal theory) developed by Robbins, identifies leadership styles that are distinguished as follows: Directive Leadership, Supportive Leadership, Participative Leadership[17].

\subsection{Organizational Culture}

Nawawi defines organizational culture is a set of values that control the interaction between members of the organization and interaction with environmental systems and other organizations [18]. Robbins culture of the organization is "a system of shared meaning held by members of the organization that distinguishes the organization from other organizations [19]." Robbins states there are seven primary characters that together capture the essence of the culture of the organization is as follows: Innovation and risk-taking, attention to accuracy, results orientation, people orientation, team orientation, aggressiveness, stability[19].

\subsection{Hypotheses}

The hypothesis of the research is as follows:

H1 : No effect of leadership style and organizational culture on job satisfaction.

$\mathrm{H} 2$ : No effect of leadership style and organizational culture on employee performance.

H3 : No effect of job satisfaction on employee performance.

H4 : No effect of leadership style and organizational culture on employee performance through job satisfaction.

\section{METHODOLOGY}

\subsection{Research Design}

The survey method used in this study. The approach is quantitative research to answer the research question. Dikumpulan data through questionnaires. Using a Likert scale as perceptional approach to facilitate the measurement. Relations latent variables and indicators are reflective. Exogenous variables System Quality is reflected by the five indicators, namely ease of use, flexibility of the system, system reliability, easy to learn, and the speed of time. Mediating variables job satisfaction is reflected five indicators of the work that is mentally challenging, the rewards are worth, working conditions that support, coworker support, conformity between the personality to the job. And an endogenous variable direflesikan performance five indicators, namely the quantity, quality, punctuality, attendance, ability to cooperate.

\subsection{Population}

Discount Bookstore Togamas employees who worked in the Corporate / headquarters in Malang. Respondents are 55 employees with job level staff working at the headquarters of Malang. In this study the technique of sampling using nonprobability sampling by census, using the population as a whole the number of samples. So respondents drawn amounted to 55 respondents.

\subsection{Data Analysis Technique}

In this study, path analysis was used to analyze the data obtained and tested hypotheses. Models are compiled in this study are inter-relationship between the number of variables that can be estimated simultaneously and in which an intermediate variable or intervening variable. In addition to the endogenous variables in the relationship that already exists, will be exogenous variables in subsequent relationships.

\section{RESULT AND DISCUSSION}

\subsection{Result}

The results of the analysis of the validity and reliability of research instruments. Product moment correlation coefficient values for each indicator study showed results above 0.266 with a significance level of less than 0000 , it indicates that the item question is able to measure the symptoms studied. Alpha Chronbach value for each variable research is still above 0.6 , indicating that the item in question is able to achieve a good level of consistency.

Figure 1 shows a summary of the results of the completed path analysis with linear regression techniques using SPSS. Multiple Linear Regression Analysis From the results of SPSS, showed that the direct effect on employee performance leadership style 0.241 , the direct effect on the performance of cultural organizations 0,308 employees, the direct effect of leadership style on 
job satisfaction is 0.333 , the direct influence of organizational culture on job satisfaction is 0.624 . The direct effect of job satisfaction on employee performance is 0.366 .

From the analysis of SPSS, R-square value obtained was 0.606and the influence of other variables, namely $39.4 \%$. This shows that the contribution of variables influence leadership style, organizational culture and job satisfaction on employee performance variable is equal to $60.6 \%$, while $39.4 \%$ variable employee performance is influenced by other variables that does not exist in research this.

Figure 1 Results Path analysis

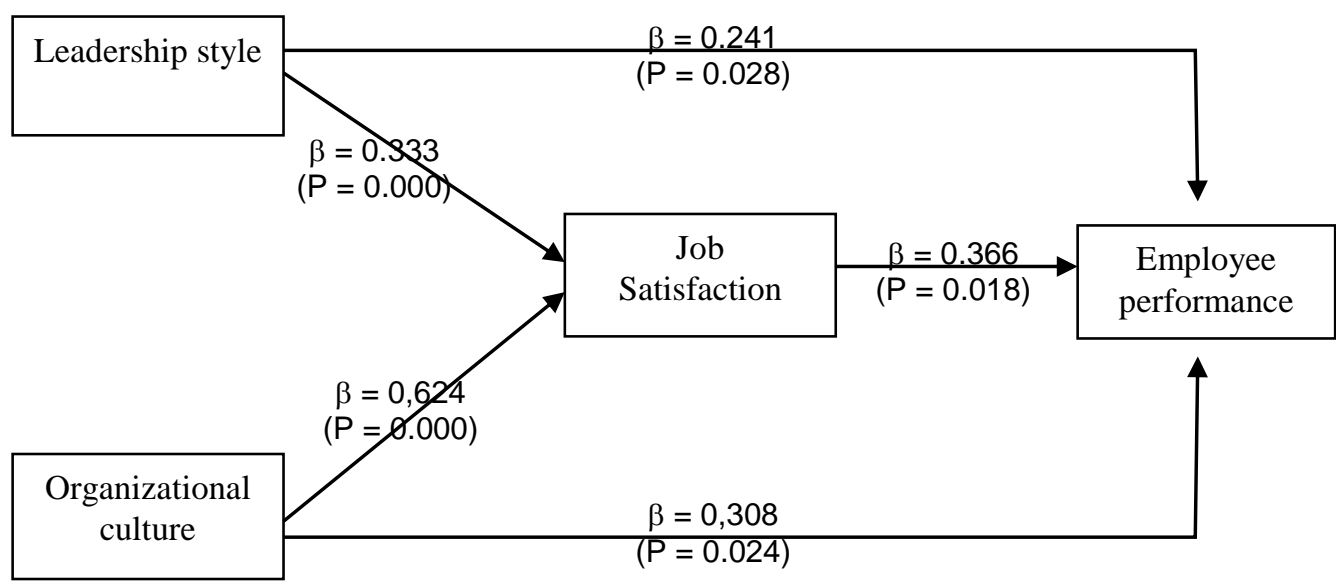

Testing causal relationship between the study variables are shown in Table 1. According to Table 1, it appears that the total effect of the variable of leadership style on employee performance $(0,363)$ is greater than the direct effect $(0.241)$. Similarly, for a variable of organizational culture on employee performance, where the total effect is greater (.536) from the direct effect (0.308). These results indicate that job satisfaction status as an intervening variable in the influence of leadership style and organizational culture on employee performance, for a total value greater than the direct effect. These results indicate that job satisfaction status as an intervening variable in the influence of leadership style and organizational culture on employee performance, for a total value greater than the direct effect.

Tabe1 1

Summary of Direct Impact Analysis, Indirect, and Total on Path Analysis

\begin{tabular}{|c|c|c|c|c|c|}
\hline Variables & $\begin{array}{l}\text { Direct } \\
\text { Effect }\end{array}$ & Prob & Indirect Effect & Total Effect & Result \\
\hline leadership style $\rightarrow$ Satisfaction & 0.333 & $0,000 *$ & - & - & \multirow{2}{*}{$\mathrm{H} 1$ = support } \\
\hline Organizational culture $\rightarrow$ Satisfaction & 0,624 & $0,000 *$ & - & - & \\
\hline leadership style $\rightarrow$ Employee performance & 0.241 & $0,028 *$ & - & - & \multirow[b]{2}{*}{$\mathrm{H} 2$ = support } \\
\hline $\begin{array}{lll}\begin{array}{l}\text { Organizational } \\
\text { performance }\end{array} & \text { culture } \rightarrow & \text { Employee } \\
& & \end{array}$ & 0,308 & $0,024 *$ & - & - & \\
\hline Satisfaction $\rightarrow$ Employee performance & 0.366 & $0,018 *$ & - & - & H3 = support \\
\hline $\begin{array}{l}\text { leadership style } \rightarrow \text { Satisfaction } \rightarrow \text { Employee } \\
\text { performance }\end{array}$ & 0.241 & - & $\begin{array}{c}0.333 \times 0.366= \\
0.122\end{array}$ & 0,363 & \multirow{2}{*}{$\mathrm{H} 4$ = support } \\
\hline $\begin{array}{l}\text { Organizational culture } \rightarrow \text { Satisfaction } \rightarrow \\
\text { Employee performance }\end{array}$ & 0,308 & - & $\begin{array}{c}0.624 \times 0.366= \\
0.228\end{array}$ & 0.536 & \\
\hline
\end{tabular}

* Sig at $\alpha 5 \%$.

\subsection{Discussion}

\subsubsection{Influence of Leadership Style and Organizational Culture Against Job satisfaction}

The leadership style influence on job satisfaction, which means that the better implementation of leadership styles applied in a company can improve employee job satisfaction. Leadership Style Indicator that gives the largest contribution in meningktkan job satisfaction is reflected Participative leadership style of the leader of providing the opportunity for employees to develop their potential. Leadership is the power to influence someone, either in doing something or not doing something, not with a subordinate 
led from the road to make or push from behind. As Soekandar view that a leader must understand the circumstances and conditions of his subordinates, to be fair and firm on all his subordinates, give and share a clear task, maintain good relations and uphold togetherness to subordinates, the leader must be aware that our employees are our most valuable assets within the enterprise, it is this which can affect the level of employee satisfaction [20]. The leader must be able to integrate the needs of subordinates with organizational needs and the needs of society as a whole, through the task of leadership that encourages subordinates in order to have a chance to develop their competence and to anticipate any challenges and opportunities for work. so the ability of a leader in mobilizing and empowering employees will affect employee satisfaction. The leadership style is individual behavior in every activity will give a result of such influences, motivations and patterns of decision-making by the employees. Employees will voluntarily do the work in order to want to achieve the objectives to be achieved. A leader must have the ability to influence subordinates in the execution of the work to achieve organizational goals effectively and efficiently. The results of this study are consistent with Nugroho et al., Raharjo et al., and Kertiriasih et al. which states that the effect of leadership style on job satisfaction $[21,22,23]$.

Organizational culture influence on job satisfaction, which means the better the culture of the organization can improve job satisfaction. Employee satisfaction is a very important factor and determine the success of the company. Indicators of organizational culture that is able to provide the largest contribution in improving job satisfaction is reflected in the attention to the precision of the Company requires to work more closely in order to avoid errors in the execution of tasks. Employee satisfaction can be realized if the company can meet the wishes of the employees in the form of work that is mentally challenging, the rewards are worth, working conditions that support, coworker support, and the fit between personality to the job. Job satisfaction is obtained if the expectations of employees can be met. As robbin views found a strong culture will lead to higher job satisfaction, whereas a weak culture will lead the organization in low job satisfaction as well [19]. Cultural organizations often will encourage team members to give birth to creative ideas and new innovation for the purpose of the organization is the organization's progress. Cultural organizations often will encourage team members to give birth to creative ideas and new innovation for the purpose of the organization is the organization's progress. This is in line with research Irawan, Putri et al., as well as Ahamed and Mahmood which states that the organizational culture influence on job satisfaction [24, 25, 26].

\subsubsection{Influence of Leadership Style and Organizational Culture on Employee Performance}

Leadership styles have a significant effect on employee performance. Demonstrated leadership style directly or indirectly, about the conviction of a leader of the ability of subordinates. As Rivai view and Mulyadi explains that "leadership style is the behavior and strategy as a result of a combination of philosophies, skills, personality traits, attitudes, which is often applied to a leader when he tried to influence the performance of subordinates" [27]. This suggests that leadership style has an important role in achieving the goals set. Therefore, a leader must have the expertise and vast knowledge gained through the development of self. The results are consistent with Raharjo et al., Hardian et al., Siswanto, Habeeb and Ibrahim, and Kertiriasih et al. which states that the effect of leadership style on employee performance [22, 29, 30, 23].

Organizational culture influence on employee performance, which means that a good organizational culture can improve employee performance. Organizational culture plays a role in influencing employee behavior can be reflected in terms of innovation and creativity opportunity, a chance to argue, a good relationship, and so on, so that the culture of the organization can function in delivering optimal performance in an effort to achieve its goals. In addition, organizational culture has a strategic role to the success of the company, such as to establish the employee's performance in the long term as a means for member organizations to meet the needs and achieve its objectives. As the view Buhler found a strong cultural norms must have high performance [31]. Behavior that is unacceptable and should be strengthened to support high performance. In addition, a strong culture also develop the commitment of the members of the organization when they receive these values. Employees prefer values, either individual values or the values of the group that had been held. Employees are also more like the way things had been done employee. If the component in the organization is not able to adjust to the changes, then this may inhibit the growth and development of companies that have an impact on employee performance. The existence of a strong organizational culture and healthy will have a positive impact on the company and with their organizational culture is strong and healthy can be used as a claim that bind the employees because it is formulated formally to the various rules and regulations of the company, thus the culture of the organization will create an increase in employee performance. The results of this study are consistent with Irawan, Wardani et al., Putri, Amanda et al., Jamaluddin et al., and Narayana which states that organizational culture influence on employee performance [24, 32, 33, 34, 35, 36].

\subsubsection{Effect of Job Satisfaction on Employee Performance}

Job satisfaction significantly influence employee performance, which means that the higher the level of employee satisfaction can improve employee performance. Job satisfaction indicators that provide the largest contribution to the increase in employee performance is reflected from their colleagues colleagues can finish the work on time. Job satisfaction is a form of pleasure for what he had done, but job satisfaction is subjective. Every employee who works expect derive satisfaction from work. 
Basically the job satisfaction is that is individualized for each employee will have the satisfaction level varies according to the values that apply in every employee. The more aspects of the work in accordance with the wishes of employees, the higher the perceived level of satisfaction. The nature and amount of satisfaction and performance depends on the contingency awards that have been set up and established by the leadership of the organization. As Luthans view that employees who have a high level of satisfaction, impact on performance will increase, although the results are not immediate [37].

Satisfaction among individual one with other people tend to be different, because each individual has a certain satisfaction criteria in measuring the level of life satisfaction, but satisfaction of employees in the work can be seen how the performance of employees. Enjoy job satisfaction in the job, off the job, and the combination of inside and outside of work. Employees who are satisfied will encourage employees to perform better. Employees who are satisfied in their work always on time, meaning that the employees appreciate the work and is responsible for the work to be done. Delighted in carrying out the work. Do not complain to the task and the work that is always able to accept new and difficult job gracefully. Has a harmonious relationship with other employees and superiors. The results are consistent with research Irawan and Kertiriasih et al. which states that job satisfaction affects the performance of employees [24, 23].

\subsubsection{Influence of Leadership Style and Culture Organization of the Employee Performance through Job Satisfaction}

Job satisfaction is able to mediate the effect of leadership style on employee performance, which means that the leadership can improve the performance of the employee, if the employee is satisfied with his work. Assessment of employees to work with her condition closely related to employee satisfaction. It is caused by a positive assessment can improve employee job satisfaction, while a negative assessment can lead to employee dissatisfaction. The ability of leaders to create a climate conducive organizations may also result in employee satisfaction. Therefore, management must be able to apply leadership appropriate to the situation and needs of employees so that a superior-subordinate relationship between harmony. Leaders recognize the existence of employees can be seen from diberikannnya opportunity for employees to be promoted and groups. This recognition can also be seen when the leadership of reprimand and a smile to the employees so that employees feel valued. The relationship between management and employees will be harmonious if the leadership is able to adjust leadership style to the situation at hand. As said Robbins and Judge that a leader able to motivate and create favorable social conditions of each employee so that the employee satisfaction with implications for increasing employee performance. The existence of appropriate leadership is expected to provide job satisfaction to employees [12].

Satisfaction capable of mediating influence of organizational culture on employee performance, which means that the employee's performance can be improved if the company has a strong organizational culture and employees are satisfied with their jobs. Job satisfaction is important for the company, if the employees are satisfied with the work provided by the company, the employee will feel cared for by the company. Organizational culture refers to a system of shared meaning held by members of the organization, which distinguishes the organization with other organizations, so that organizational culture was grown and evolved into the personality and strength of the organization. As the results Simmons that organizational culture fosters employee empowerment and trust in the management of that associated with high job satisfaction and impact on improving employee performance [38]. Basically, the employees would feel comfortable working in organizations when obtaining job satisfaction. The employee's performance will be influenced by the level of job satisfaction owned. When employees feel satisfaction with the work done, then the employee will work optimally in completing the work, even doing some things that may be beyond his duties.

Greater job satisfaction mediates the influence of organizational culture than the leadership style on employee performance. This proves that a strong organizational culture is the key kesuksean Togamas Discount Bookstore. Strong culture means that the organization's core values truly become an ideology, which is adhered to and applied in everyday life in the workplace. Strong organizational culture can be a place where everyone has a very clear idea, of what you want employees to give and contribute to the future of the employees and the organization. Strong organizational culture can create independence of the work in a safe and comfortable environment, and allows each employee to learn, grow, and focus on the daily work of employees. Research shows that Cultural Organization which was created Bookstores Discounts are conducive Togamas can cause job satisfaction. Employees who feel comfortable and satisfied with his work, employees can work and think more creatively for the advancement of the organization that have an impact on employee performance improvement in terms of quantity, quality and timely in completing the work.

\section{CONCLUSIONS AND SUGGESTION}

\subsection{Conclusion}

1) Leadership style and organizational culture influence on job satisfaction, which means that the leadership style applied and supported organizational culture that can increase job satisfaction.

2) Leadership style and organizational culture influence on employee performance. This means that the performance of employees can be built through good leadership style and the company has a strong organizational culture. 
3) Job satisfaction affects the performance of employees, which means that employee satisfaction in finishing the work can improve employee performance.

4) Satisfaction mediate the effect of leadership style and organizational culture on employee performance. This means that the performance of employees can be built if the employee is satisfied with the leadership styles applied in the company and the company has a good organizational culture.

\subsection{Suggestion}

In connection with the matters described above, it can be given suggestions as follows:

1) theoretically

This study enriches the conception of the understanding of human resource management, it is necessary to develop models and conception of the performance of employees with job satisfaction approach.

2) practically

a. For researchers that by doing this research can be seen leadership style and organizational culture on performance through job satisfaction.

b. For Togamas Discount Bookstore, with this research is to improve job satisfaction have an impact on employee performance improvement.

c. For subsequent researchers, it needs a broader development with variables that not only the style of leadership, organizational culture that can affect the performance of employees, such as the ability and creativity.

\section{REFERENCES}

1. Yukl, Gary A.2005. Kepemimpinan Dalam Organisasi. Edisi Kelima. Jakata: PT. INDEKS.

2. Kartono, Kartini. Pemimpin dan Kepemimpinan. Jakarta: PT Raja Grafindo Persada, 2011.

3. Mondiani, Tria. 2012. Pengaruh Kepemimpinan Transformasional dan Kompensasi Terhadap Kinerja Karyawan PT. PLN (PERSERO) UPJ SEMARANG. Jurnal Administrasi Bisnis. Volume I Nomor 1 September 2012.

4. Gibson, M. 2008. Manajemen Sumber Daya Manusia. Cetakan ke dua. Jakarta: Erlangga.

5. Sutanto, Aftoni. 2002. Peran Budaya Organisasional untuk meningkatkan Kepuasan Kerja dan Kinerja Karyawan. Benefit, Vol. 6, No. 02, Desember, Hal. 120-130.

6. Wibowo. 2010. Manajemen Kinerja. Jakarta: Rajawali Press.

7. Robbins, P.Stephen dan Timothy A. Judge. 2012. Perilaku Organisasi. Salemba Empat. Jakarta

8. Bernardin, H.J. \& Russel, J.E.A 1993. Human Resource Management an experiental approach. Singapore: Mc GrawHill, Inc.

9. As'ad, Moh., 1999. Seri Ilmu Sumber Daya Manusia - Pikologi Industri, Yogyakarta: Liberty.

10. Mathis, Robert L. dan John H. Jackson. 2012. Manajemen Sumber Daya Manusia. Edisi Pertama Salemba Empat, Jakarta.

11. Mangkunegara, A.A Anwar Prabu. 2009. Manajemen Sumber Daya Manusia Perusahaan. Bandung: Remaja Rosadakarya.

12. Robbins SP, dan Judge. 2007. Perilaku Organisasi, Salemba Empat, Jakarta.

13. Hasibuan, Malayu. 2008. Manajemen Dasar, Pengertian, dan Masalah. Jakarta: PT Bumi Aksara.

14. Gibson, James L. dkk. 2006. Organizations Behaviour, Struture, Processes. Dallas: Business Pub.

15. Robbins, Stephen P. \& A. Judge, Timothy.2011. Organizational behavior. Fourteenth Edition. Pearson education. New Jersey 07458. 77-89.

16. Thoha, Miftah. 2005. Perilaku Organisasi :Konsep Dasar dan Aplikasinya. Jakarta: Raja Grafindo Persada.

17. Robbins, Stephen. 2008. Perilaku Organisasi : Konsep, Kontroversi, Aplikasi. Edisi Bahasa Indonesia. Alih Bahasa : Pujatmoko, Hudiana. Penerbit Prenhallindo. Jakarta.

18. Nawawi, Hadari. 2006. Evaluasi dan Manajemen Kinerja di Lingkungan Perusahaan Dan Industri. Yogyakarta: Gadjah Mada Univercity Press.

19. Robbins, Stephen P. 2006. Perilaku Organisasi. Edisi kesepuluh. Jakarta: PT Indeks Kelompok Gramedia

20. Soekandar, 2010, Karyawan Dalam Perusahaan http://human.resource. management.com/2010/05/16/ meningkatkankepuasan kerjakaryawan,[16/Feb/2013] ).

21. Nugroho dan Suwarti. 2005. Pengaruh Gaya Kepemimpinan Terhadap Kepuasan Kerja Dengan Moderasi Motivasi (Studi pada Komisi Pemilihan Umum Kabupaten Grobogan). Telaah Manajemen, Magister Universitas Stikubank Semarang. Vol. 2. Edisi 3: $22-36$.

22. Raharjo, Susilo Toto dan Durrotin Nafisah. 2006. Analisis Analisis Pengaruh Gaya Kepemimpinan Terhadap Kepuasan Kerja, Komitmen Organisasi dan Kinerja Karyawan (Studi Empiris Pada Departemen Agama Kabupaten Kendal Dan Departemen Agama Kota Semarang). Jurnal Studi Manajemen \& Organisasi. Volume 3. Nomor 2: 69-81. 
23. Kertiriasih, Ni Nengah Rupadi, I Wayan Sujana, dan I Nengah Suardika. 2018. The Effect of Leadership Style to Job Satisfaction, Employee Engagement and Employee Performance (Study at PT. Interbat, Bali, Nusra, and Ambon). International Journal of Contemporary Research and Review. Volume 09 Issue 03: 20592 - 20600.

24. Irawan, Koko. 2010. Potensi Obyek Wisata Sebagai Daya Tarik Wisata. Yogyakarta: Kertas Karya

25. Putri, Ade Kamelia, Susi Henriani dan Rendra Wasnury. 2015. Pengaruh Budaya Organisasi dan Lingkungan Kerja Terhadap Kepuasan Kerja Guru pada SMK Negeri 1 Dumai. Jom FEKON. Vol 2. No.1: 1-15.

26. Ahamed, Maruf dan Rezwan Mahmood. 2015. Impact of Organizational Culture on Job Satisfaction: A Study on Banglalion Communication td, Bangladesh. European Journal of Business and Management. Vol 7. No. 10: 160 - 175.

27. Rivai, Veithzal. dan Deddy Mulyadi 2009. Kepemimpinan dan Perilaku Organisasi. Jakarta: PT Raja Grafindo Persada.

28. Hardian, Ferry, Kusdi Rahardjo dan Moch. Soe;ed Hakam. 2015. Pengaruh Gaya Kepemimpinan Terhadap Kinerja Karyawan (Studi Pada Karyawan Tetap Service Center Panasonic Surabaya). Jurnal Administrasi Bisnis (JAB). Vol. 1 No. 1: 1-7.

29. Siswanto, Rendyka Dio dan Djambur Hamid. 2017. Pengaruh Gaya Kepemimpinan Terhadap Kinerja Karyawan (Studi pada karyawan divisi Human Resources Management Compensation and Benefits PT Freeport Indonesia). Jurnal Administrasi Bisnis (JAB). Vol. 42. No. 1: 189 - 198.

30. Habeeb, Munirat Yusuf dan Yusuf Ibrahim. 2017. Effects of Leadership Style on Employee Performance in Nigerian Universities. Global Journal of Management and Business Research: A Administration and Management. Volume 17 Issue 7 Version 1.0: 1-8.

31. Buhler, Michael. 2007. Performance Management. Tugu Publisher. Yogyakarta.

32. Wardani, Rodiathul Kusuma, M. Djudi Mukzan dan Yuniadi Mayowan. 2016. Pengaruh Budaya Organisasi Terhadap Kinerja Karyawan (Studi Pada Karyawan PT Karya Indah Buana Surabaya). Jurnal Administrasi Bisnis. Volume 31 No. 1: 58-65.

33. Putri, Isnanindia Septia. 2016. Pengaruh Budaya Organisasi Terhadap Kinerja Pegawai di Dinas Pendidikan dan Kebudayaan Kota Samarinda. e-journal administrasi negara. Volume 4. Nomor 4: 4802-4816.

34. Amanda, Ayu. Agung \& Widi, Hening. Oetomo 2017. Pengaruh stres kerja, motivasi kerja, dan kompensasi terhadap kinerja karyawan. Jurnal Ilmu dan Riset Manajemen. Vol 6, No 7: 85 - 92.

35. Jamaluddin, Rudi Salam, Harisman Yunus dan Hedar Akib. 2017. Pengaruh Budaya Organisasi terhadap Kinerja Pegawai pada Dinas Pendidikan Provinsi Sulawesi Selatan. Jurnal Administrate: Jurnal Pemikiran Ilmiah dan Pendidikan Administrasi Perkantoran. Vol. 4. No. 1: 25-34.

36. Narayana, Ananta. 2017. A Critical Review of Organizational Culture on Employee Performance. American Journal of Engineering and Technology Management. Vol 2. No. 5: 72-76.

37. Luthans, Fred. 2006. Perilaku Organisasi. Edisi 10. Yogyakarta : Andi.

38. Simmons., E. S. 2005. Predictors of Organizational Commitment Among Staff in Assisted Living. The Gerontologist. Vol.45, 196-205. 